\author{
Aneta Pawłowska-Legwand \\ D https://orcid.org/0000-0001-7819-6312 \\ Uniwersytet Jagielloński w Krakowie \\ Wydział Geografii i Geologii \\ Instytut Geografii i Gospodarki Przestrzennej \\ Zakład Gospodarki Turystycznej i Uzdrowiskowej \\ aa.pawlowska@uj.edu.pl
}

\title{
WYKORZYSTANIE TECHNOLOGII INFORMACYJNO-KOMUNIKACYJNYCH W DOSTĘPIE DO INFORMACJI I USŁUG TURYSTYCZNYCH W ŚWIETLE WYNIKÓW BADAŃ PRZEPROWADZONYCH WŚRÓD POLSKICH TURYSTÓW W WOJEWÓDZTWIE MAŁOPOLSKIM ${ }^{1}$
}

\begin{abstract}
Abstrakt: Technologie informacyjno-komunikacyjne znalazły szerokie zastosowanie w dostępie do informacji i usług turystycznych, a korzystanie z tego typu rozwiązań oddziałuje na zachowania turystyczne. Celem autorki artykułu było scharakteryzowanie na podstawie wyników przeprowadzonych badań zachowań i opinii turystów w zakresie korzystania $\mathrm{z}$ tych technologii przed planowaną podróżą. Wyniki te, w tym ocena użyteczności narzędzi cyfrowych, wskazują, że turyści są zainteresowani korzystaniem z technologii informacyjno-komunikacyjnych. Najbardziej aktywnymi użytkownikami byli respondenci w wieku poniżej 35 lat, mieszkający w miastach i mający wykształcenie średnie lub wyższe. Strony internetowe, aplikacje mobilne i inne rozwiązania utworzone z zastosowaniem omawianych technologii były traktowane przez nich przede wszystkim jako źródło szeroko rozumianej informacji turystycznej oraz narzędzie ułatwiające planowanie trasy przemieszczania się, a także kupowanie usług turystycznych. Dla podróżnych miały również znaczenie media społecznościowe, umożliwiające dzielenie się w Internecie treściami związanymi z wyjazdem turystycznym.
\end{abstract}

Słowa kluczowe: technologie informacyjno-komunikacyjne, informacja i usługi turystyczne, badanie ankietowe, zogniskowane wywiady grupowe.

\section{WSTĘP}

W ostatnich latach wzrosła rola technologii informacyjno-komunikacyjnych $w$ dostępie do informacji i usług elektronicznych (e-usług), co łączy się z rozwojem społeczeństwa informacyjnego (Giddens, 2008). Dotyczy to również informacji i usług turystycznych, z których obecnie można korzystać w przestrzeni wirtualnej i poza nią za pośrednictwem różnorodnych narzędzi cyfrowych. W konsekwencji postępu technologicznego systematycznie rozwija się e-turystyka (Buhalis, 2003) oraz „inteligentna turystyka" (smart tourism), w których znaczenie mają duże zbiory danych big data i Internet rzeczy (Gretzel, Sigala, Xiang, Koo, 2015).

Etap korzystania $\mathrm{z}$ informacji jest podkreślany w modelach zachowania turysty $\mathrm{w}$ przestrzeni geograficznej (Hall, 2006; Kowalczyk, 2000; Mika, 2014; Richards, 2002) oraz konsumenta na rynku turystycznym (Kotler, Bowen, Makens, 2006). Z perspektywy konsumenta dostęp do technologii informacyjno-komunikacyjnych może skutkować zwiększaniem użyteczności miejsca, czasu i formy oraz zmniejszaniem kosztów korzystania $\mathrm{z}$ informacji i usług turystycznych (Kachniewska, 2011). Za ich pośrednictwem jest możliwe uzyskanie wiedzy, zredukowanie ryzyka związanego z zakupem i ukształtowanie percepcji podróży (Kotler, Bowen, Makens, 2006). Kluczowe znaczenie w korzystaniu z narzędzi cyfrowych ma indywidualne postrzeganie ich jako użytecznych w realizacji różnych działań związanych z wyjazdem turystycznym (Amaro, Duarte, 2015; Kim, Park, Morrison, 2008; di Pietro, di Virgiglio, Pantano, 2011). Charakteryzując relacje między turystą a przestrzenią geograficzną, Mika (2014) podkreślił, że poznawanie i wartościowanie (co łączy się z korzystaniem z informacji o walorach i zagospodarowaniu turystycznym) poprzedza użytkowanie jej w celu realizacji potrzeb. Wyjazd turystyczny angażuje ludzi czasowo, finansowo i emocjonalnie, dlatego istotne znaczenie ma dostęp do dokładnej, sprawdzonej i rzetelnej informacji (Marciszewska, 2010). Horner i Swarbrooke (2016) zwrócili z kolei uwagę na 
emocjonalne czynniki motywujące. $Z$ jednej strony mogą one zmniejszać zaangażowanie $\mathrm{w}$ analizowanie informacji przed decyzją związaną z uczestnictwem $\mathrm{w}$ turystyce, z drugiej zaś - powodować bardziej szczegółowe poszukiwania (Horner, Swarbrooke, 2016).

W badaniach nad korzystaniem z narzędzi cyfrowych przez turystów podkreśla się, oprócz wspomnianego wyżej postrzegania użyteczności, również kształtowanie doświadczenia turystycznego. Obecnie konsumenci stają się coraz bardziej niezależni, samodzielni i wymagający na etapie poszukiwania informacji przed decyzją nabywczą związaną z wyjazdem turystycznym (Niininen, Buhalis, March, 2007). Poszukują informacji i ofert, które będą optymalnie dostosowane do ich potrzeb (Niemczyk, 2017a), przez co zapewnią im autentyczne i unikatowe doświadczenia, a także okażą się korzystne czasowo i finansowo (Gaworecki, 2007). Turyści pragną satysfakcjonującej równowagi między jakością i ceną (Buhalis, O'Connor, 2005) a doświadczeniem turystycznym (Zehrer, Pechlaner, Hölzl, 2005). W tym kontekście technologie informacyjno-komunikacyjne znajdują zastosowanie na etapie kupowania, przeżywania i zapamiętywania doświadczenia turystycznego (Horner, Swarbrooke, 2016). Korzystanie z nich może pomóc w podjęciu decyzji nabywczej (Buhalis, Law, 2008; Buhalis, O'Connor, 2005; Niininen, Buhalis, March, 2007) i współtworzyć doświadczenie turystyczne na etapie przygotowań, pobytu i powrotu z podróży (Neuhofer, Buhalis, Ladkin, 2012, 2014).

Neuhofer, Buhalis i Ladkin (2014) opisali trzy poziomy doświadczenia turystycznego, w zależności od zakresu korzystania z narzędzi cyfrowych. W tym modelu technologiom przypisuje się funkcję współtworzenia doświadczenia turystycznego. Wspomniane poziomy kształtuje korzystanie $\mathrm{z}$ takich rozwiązań, jak np. systemy rezerwacyjne i internetowe biura podróży, media społecznościowe, technologie i urządzenia mobilne oraz usługi geolokalizacyjne, rzeczywistość rozszerzona (Neuhofer, Buhalis, Ladkin, 2014). Charakteryzując zachowania e-turystów, Panasiuk (2015) zwrócił uwagę na zróżnicowanie w tym, w jaki sposób konsumenci korzystają z informacji i narzędzi w Internecie, aby powziąć decyzje zakupowe dotyczące usług i/lub destynacji turystycznych. Mogą oni ułatwić sobie podejmowanie decyzji poprzez korzystanie z rozwiązań cyfrowych w różnym zakresie, w zależności od sposobu postrzegania korzyści, jakie to przynosi (Panasiuk, 2015).

W turystyce szczególnego znaczenia w ostatnich latach nabrały media społecznościowe, które ze względu na interaktywność i zawartość treści generowanych przez użytkowników są traktowane jako wiarygodne i użyteczne źródło informacji szybko i łatwo dostępnej (Law, Buhalis, Cobanoglu, 2015). Treści te charakteryzują się opiniotwórczością, przez co stają się nośnikiem ocen i trendów kształtujących potrzeby i zachowania, również związane $\mathrm{z}$ uczestnictwem $\mathrm{w}$ turystyce (Buhalis,
Leung, Law, 2011; Meyer, 2015; Xiang, Gretzel, 2010; Zeng, Gerritsen, 2014). Co więcej, dzielenie się własnymi doświadczeniami turystycznymi w Internecie jest traktowane jako przydatne dla innych (Munar, Jacobsen, 2014).

Xiang, Magnini i Fesenmaier (2015) zwrócili uwage na charakterystyczne „rozdwojenie” w zachowaniu konsumenta, związane z korzystaniem ze źródeł i narzędzi internetowych w planowaniu wyjazdu turystycznego. Aktywność ta może obejmować stosowanie znanych sobie rozwiązań na podstawie nabytych nawyków lub źródeł i narzędzi internetowych coraz bardziej zróżnicowanych, takich jak: media społecznościowe oraz aplikacje mobilne i internetowe biura podróży, w celu optymalnego zaplanowania doświadczenia turystycznego. Co istotne, mogą być one łączone ze źródłami i narzędziami tradycyjnymi. Ponadto dostęp do Internetu za pośrednictwem urządzeń przenośnych wprowadził zasadniczą zmianę w etapie poszukiwania informacji, który jest odkładany $\mathrm{w}$ czasie, $\mathrm{np}$. do pobytu $\mathrm{w}$ miejscu docelowym (Xiang, Magnini, Fesenmaier, 2015).

Obecnie zastosowanie technologii informacyjno-komunikacyjnych jest wskazywane w opracowaniach dotyczących rozwoju turystyki jako jeden z trendów kształtujących tę gałąź gospodarki w średniej i długiej perspektywie, co omówił Rudnicki (2017). Nastąpi dalszy rozwój elektronicznych kanałów dystrybucji informacji i usług turystycznych, w tym rynku e-pośredników, a zachowania konsumenckie będą realizowane $\mathrm{w}$ coraz szerszym zakresie w Internecie. Aktywność ta umożliwi analizowanie i zastosowanie big data do wnioskowania nt. zachowania konsumenta $w$ procesach biznesowych. Z mediami społecznościowymi łączy się wzrost znaczenia treści zamieszczanych przez twórców internetowych, takich jak: blogerzy i vlogerzy, oraz opinii użytkowników. W konsekwencji treści te będą kształtować nie tylko zachowanie konsumenta, ale również działania marketingowe obiektu lub miejsca. Szersze zastosowanie znajdą: technologia mobilna, rzeczywistość wirtualna i wyszukiwanie semantyczne (Rudnicki, 2017).

\section{PRZEGLĄD DOTYCHCZASOWYCH WYNIKÓW BADAŃ DOTYCZĄCYCH TURYSTÓW W POLSCE}

Rosnąca dostępność, różnorodność i popularność źródeł informacji oraz narzędzi dostępu do usług, które są tworzone z zastosowaniem technologii informacyjno-komunikacyjnych spowodowała zwiększenie się zainteresowania turystów korzystaniem z nich. Jak podkreślili Jaremen, Michalska-Dudek i Rapacz (2016), na rynku turystycznym postępuje wirtualizacja zachowań konsumenta, ponieważ obecnie turyści realizują swoje potrzeby informacyjne na kolejnych etapach podróży w du- 
żej mierze za pośrednictwem Internetu. Patrząc szerzej, rozwój technologii informacyjno-komunikacyjnych umożliwił digitalizację informacji (Kachniewska, 2017), a korzystanie $\mathrm{z}$ nich kształtuje doświadczenie turystyczne (Berbeka, 2017).

Zainteresowanie korzystaniem z Internetu, który coraz częściej jest traktowany jako główne źródło informacji o atrakcjach turystycznych $(60 \%)$, łączy się z rezygnowaniem z kupna publikacji tematycznych $(54,8 \%)$, rzadziej z tradycyjnego pośrednictwa turystycznego $(9,9 \%)$ (Jaremen, Michalska-Dudek, Rapacz, 2016), co nawiązuje do charakterystyki e-konsumenta autorstwa Panasiuka (2015). Na etapie podejmowania decyzji o miejscu docelowym wyjazdu turystycznego ma znaczenie nie tylko dostęp do informacji, ale również sposób jej wizualizacji (Kachniewska, 2017). Tu zaznacza się wpływ na zachowania turystyczne treści z różnego rodzaju mediów społecznościowych, ze szczególnym uwzględnieniem fotografii (Poczta, Mariianchuk, 2013).

Wyniki badania przeprowadzonego przez Jaremen, Michalską-Dudek i Rapacza (2016) na Dolnym Śląsku ( $\mathrm{n}=343$ ) dowodzą dużego zainteresowania respondentów poszukiwaniem informacji w Internecie (por. Smul, 2013), zarówno przed wyjazdem turystycznym $(90 \%)$, jak i podczas niego $(83 \%)$. Podobne wyniki uzyskano w badaniu w Krakowie (n = 1175), które omówiła Berbeka (2017). Przed wyjazdem turystycznym są wykorzystywane różnorodne źródła informacji, m.in. portal turystyczny $(59,55 \%)$, strona internetowa jednostki samorządu terytorialnego lub organizacji turystycznej (42,21\%), media społecznościowe - konto Facebook i blog (ok. 40\%). Internet zyskał na znaczeniu również jako narzędzie zakupu usług turystycznych $(81 \%)$, przede wszystkim noclegowych (71,46\%) (najczęściej Booking.com), oraz biletów przejazdowych, głównie kolejowych/autobusowych $(63,21 \%)$ i lotniczych $(54,02 \%)$, rzadziej komunikacji miejskiej (24,95\%) (Berbeka, 2017).

Wśród polskich turystów coraz bardziej widoczne jest zainteresowanie mediami społecznościowymi w kontekście wyjazdu turystycznego zarówno w korzystaniu $\mathrm{z}$ informacji, udostępnionej przez innych użytkowników, jak i w zamieszczaniu informacji o swoich podróżach (Berbeka, 2017; Jaremen, Michalska-Dudek, Rapacz, 2016; Niemczyk, 2017b; Seweryn, 2015). Te dane mogą być z kolei przedmiotem różnorodnych analiz. Zajadacz (2017) jako przykład podała badanie dyssatysfakcji $\mathrm{z}$ atrakcji turystycznych na podstawie treści w serwisie rekomendacyjnym TripAdvisor.

Zainteresowanie mediami społecznościowymi dotyczy nie tylko różnego rodzaju serwisów społecznościowych, ale też w dużej mierze działalności twórców internetowych. Jakubowska (2018), analizując treści na polskich blogach o tematyce podróżniczej $(n=41)$, zwróciła uwagę na popularyzowanie przez autorów określonych form turystyki. Przede wszystkim była to turystyka wypoczynkowa $(100 \%)$, poznawcza $(98 \%)$ i kwalifikowana
(55\%) na obszarach miejskich (93\%), nadmorskich (61\%) i górskich (54\%), przy czym na $66 \%$ analizowanych blogów wspomniane formy turystyki opisano w kontekście wyjazdów krajowych (Jakubowska, 2018). Z kolei Lisowska i Wieszaczewska (2017) podkreśliły, że tego rodzaju narracje mogą pośredniczyć $\mathrm{w}$ kreowaniu potrzeb i wyobrażeń turystów (por. Morozova, 2016). Autorki analizowały wpisy na blogach podróżniczych poświęcone pielgrzymowaniu do Santiago de Compostela $(n=5)$, jednak wniosek ten można odnieść też do innych form turystyki (Lisowska, Wieszaczewska, 2017). Morozova (2016), także na podstawie analizy blogów podróżniczych $(n=23)$, podkreśliła znaczenie doradztwa ze strony autorów, szeroko rozumianego, przez udostępnianie porad, rankingów i wyników testów. Czytelnicy, będący potencjalnymi turystami, mogą postrzegać te informacje jako rekomendacje dotyczące miejsc, obiektów i/lub sprzętu, które będą użyteczne dla nich podczas organizacji wyjazdu turystycznego (Morozova, 2016). Za pomocą blogów można propagować określone wzorce (Morozova, 2016) i alternatywne sposoby podróżowania (Jednoralska, 2016). Z tej perspektywy ciekawym kierunkiem badań może być analiza zachowań i opinii turystów w zakresie korzystania z treści tego rodzaju.

Dostęp do informacji i usług turystycznych rozszerza się przez korzystanie z aplikacji mobilnych. Kubiak (2015), omawiając to zagadnienie na przykładzie aplikacji z informacją turystyczną dla Torunia i Poznania ( $n=103)$, zwrócił uwagę na kwestię użyteczności. Korzystanie za pomocą smartfona z informacji turystycznej bezpośrednio $\mathrm{w}$ aplikacji zadeklarowała $1 / 4$ respondentów, a w Internecie - blisko $1 / 3$ z nich. Najistotniejszymi cechami aplikacji dla użytkowników są: przydatność (34\%) i dostępne treści (21\%), co ma kluczowe znaczenie dla ocenienia jej jako użytecznej i zaspokojenia potrzeby informacyjnej. Zestawienie ocen aplikacji ze sklepu internetowego opracowane przez Zawadzkiego (2018) daje pogląd na zainteresowanie korzystaniem $\mathrm{z}$ tego źródła informacji turystycznej dla wybranych polskich miast (oceny od 3,0 do 4,6) i regionów (oceny od 3,9 do 4,8$)$.

Na sposób i zakres korzystania z narzędzi cyfrowych przez polskich turystów wpływają cechy demograficzno-społeczne. Większym zainteresowaniem narzędzia te cieszą się w "młodszych" grupach wiekowych. Jest to powiązane z cechami pokoleń X, Y i Z, charakteryzowanymi jako bardziej aktywne, gdy chodzi o uczestniczenie $w$ turystyce i korzystanie $\mathrm{z}$ technologii informacyjno-komunikacyjnych, również w kontekście organizacji wyjazdu turystycznego (Zajadacz, 2014). Osoby z grupy do 35. roku życia częściej organizują wyjazd turystyczny, stosując narzędzia cyfrowe (Jaremen, Michalska-Dudek, Rapacz, 2016; por. Berbeka, 2017). Oprócz wieku na korzystanie z cyfrowych źródeł informacji turystycznej wpływają takie cechy, jak: miejsce zamieszkania, wykształcenie i status zawodowy, natomiast na działania 
związane z płatnościami elektronicznymi za usługi turystyczne rzutuje również sytuacja materialna (Berbeka, 2017). W przypadku wieku podobna zależność była widoczna w wynikach badania przeprowadzonego w Krakowie - omówionych przez Seweryn (2015; n = 3651) - w zakresie poszukiwania informacji turystycznej w mediach społecznościowych. Bardziej aktywne były osoby w wieku do 40 lat i mieszkające w większych miastach (Seweryn, 2015). Jak wynika z badań Rasińskiej i Siwińskiego (2015), przeprowadzonych w Poznaniu ( $n=268)$, respondenci w wieku studenckim $(97 \%)$ są zdania, że urządzenia i aplikacje mobilne, łącząc różne funkcje, mogą zastąpić przewodnik drukowany, aparat fotograficzny, kamerę i urządzenie nawigacyjne.

Korzystanie przez polskich turystów z technologii informacyjno-komunikacyjnych jest często głównym celem badań ankietowych. Jednak analizie mogą podlegać również big data, generowane podczas korzystania $\mathrm{z}$ narzędzi cyfrowych, np. dane demograficzne, informacje o zachowaniach nabywczych, opiniach i odczuciach (Kachniewska, 2014). Majewska, Napierała i Adamiak (2016) podkreślili, na przykładzie analizy zdjęć wykonanych w Krakowskim Obszarze Metropolitalnym i udostępnionych w Wikimedia Commons, że treści zamieszczane w mediach społecznościowych można rozpatrywać w kategoriach oceniania atrakcyjności turystycznej i postrzegania przestrzeni turystycznej. Kachniewska (2014), omawiając wyniki panelu eksperckiego, jako korzyści związane z big data wymieniła możliwość prognozowania i analizowania trendów konsumenckich, a następnie tworzenie na tej podstawie nowych produktów, co - szerzej patrząc - dotyczy projektowania indywidualnego i kompleksowego doświadczenia turystycznego. W konsekwencji te działania mogą kształtować przewagę konkurencyjną przedsiębiorstw i regionów turystycznych (Kachniewska, 2014).

\section{CELE I METODY}

Celem autorki artykułu było scharakteryzowanie zachowań oraz opinii turystów w zakresie korzystania $\mathrm{z}$ technologii informacyjno-komunikacyjnych przed podróżą na podstawie wyników końcowych przeprowadzonych badań (por. Pawłowska, 2015, 2016a, 2016b). Do poznania tej aktywności uczestników ruchu turystycznego dążono podczas badania ankietowego dotyczącego stosowania narzędzi cyfrowych i zogniskowanych wywiadów grupowych, uzupełniających uzyskane wyniki ankietowania. W niniejszym opracowaniu skupiono się na omówieniu zakresu korzystania z narzędzi cyfrowych oraz oceny ich użyteczności.

Badanie ankietowe przeprowadzono w latach 20142016 w ośrodkach turystycznych województwa małopolskiego na próbie 1053 respondentów (dobór losowy), tj. w Krakowie (400), Krynicy-Zdroju (100), Nowym Targu (300), Szczawnicy (100), Wieliczce (53) i Zakopanem (100). Ankietowanie odbyło się w trzech etapach, tj. w okresach: wrzesień-grudzień 2014 r., marzec-wrzesień 2015 r., luty-czerwiec 2016 r. Wykorzystano standaryzowany kwestionariusz wywiadu z 25 pytaniami (24 pytania zamknięte lub półotwarte i 1 otwarte), który był wypełniany przez ankietera. Respondentami byli krajowi turyści przyjazdowi, korzystający z noclegu lub nie.

$\mathrm{W}$ analizie statystycznej uwzględniono odpowiedzi od 973 respondentów (w tym 51\% kobiet i 49\% mężczyzn). Ankietowani w wieku 19-25 lat stanowili 30\%, podobnie osoby w grupie wiekowej 26-35 lat -31\%, natomiast respondenci powyżej 35. roku życia - łącznie $36 \%$. Tylko 4\% ankietowanych miało 15-18 lat. Większość uczestników ankiety mieszkała w miastach $(87 \%)$, w tym ok. $1 / 3$ (34\%) z nich w dużych miastach o liczbie ludności powyżej 500 tys. mieszkańców. Połowa badanych (51\%) miała wykształcenie wyższe, 39\% - średnie, $7 \%$ - zawodowe, a 3\% - podstawowe (w tym w $91 \%$ byli to uczniowie szkół średnich).

Zogniskowane wywiady grupowe przeprowadzono w 2016 r. (dobór celowy), po zakończeniu badania ankietowego. Na podstawie jego wyników stwierdzono, że osoby w wieku od 15 do 35 lat najbardziej aktywnie korzystały z technologii informacyjno-komunikacyjnych w odniesieniu do wyjazdu turystycznego. Zogniskowane wywiady grupowe $\mathrm{z}$ respondentami ze wspomnianej grupy wiekowej umożliwiły szczegółowe poznanie badanych zagadnień z punktu widzenia tych osób.

Pytania otwarte zadawano na podstawie scenariusza. Wywiady zarejestrowano cyfrowo i sporządzono transkrypcję. W artykule wykorzystano wyniki wywiadów, w których wzięło udział 45 respondentów w wieku od 15 do 35 lat, w podziale na pięć grup fokusowych, w tym $60 \%$ kobiet i $40 \%$ mężczyzn. Wywiady trwały po 45-60 minut $\mathrm{z}$ „młodszymi” respondentami, w wieku 15-18 lat (dwie grupy po 15 osób), z wykształceniem podstawowym, a po 60-90 minut ze "starszymi", w wieku od 19 do 35 lat (trzy grupy po 5 osób), z wykształceniem średnim i wyższym. Byli to mieszkańcy miast, w tym w 66\% miast o liczbie ludności powyżej 500 tys.

\section{WYNIKI BADAŃ}

\subsection{KORZYSTANIE Z TECHNOLOGII INFORMACYJNO- -KOMUNIKACYJNYCH PRZED WYJAZDEM TURYSTYCZNYM}

Blisko 70\% respondentów, przygotowując się do wyjazdu turystycznego, korzystało z Internetu zawsze (31\%) lub często (35\%). Natomiast $12 \%$ z nich robiło to rzad- 
ko, a $4 \%$ nigdy. To pytanie miało charakter wprowadzający, a badane kwestie uszczegółowiono w kolejnych.

W zestawieniu odpowiedzi z cechami demograficznymi respondentów, podobnie jak dla większości pozostałych pytań, były widoczne pewne elementy charakterystyczne. Biorąc pod uwagę wiek, najbardziej aktywnymi użytkownikami byli respondenci poniżej 35. roku życia (test Kruskala-Wallisa: $H=53,13, p=0,000$ ) (tab. 1), a uwzględniając wykształcenie - ci z wykształceniem wyższym (test Kruskala-Wallisa: $\mathrm{H}=100,96, p=0,000$ ). Zawsze i często korzystało z Internetu $3 / 4 \mathrm{z}$ nich (76\%), podobnie $\mathrm{z}$ wykształceniem podstawowym $-72 \%$, mniej licznie ze średnim - 59\%, a najrzadziej z zawodowym $-26 \%$. Blisko $1 / 3$ ankietowanych $z$ wykształceniem zawodowym w ogóle nie korzystała $\mathrm{z}$ Internetu $\mathrm{w}$ badanym zakresie. Częściej korzystali z niego respondenci z miast o liczbie ludności powyżej 500 tys., w porównaniu z mieszkańcami mniejszych miast i obszarów wiejskich (test Kruskala-Wallisa: $\mathrm{H}=156,27, p=0,000$ ). Ponad połowa uczestników badania z miast powyżej 500 tys. ludności używała Internetu zawsze $(56 \%)$, a ponad $1 / 4$ - często (28\%).

Ankietowani, zapytani o cele korzystania z Internetu (rys. 1), wskazywali najczęściej szukanie informacji turystycznej (85\%). Korzystali w tym celu przede wszystkim ze strony internetowej odwiedzanego miejsca (56\%), np. z oficjalnej strony internetowej jednostki samorządu terytorialnego, oraz z ogólnopolskiego portalu internetowego $\mathrm{z}$ działem tematycznym o podróżach (42\%). Mniej liczne odpowiedzi dotyczyły tematycznego serwisu internetowego (36\%), również np. jednostek samorządu terytorialnego. Respondenci byli zainteresowani opiniami użytkowników, np. o usługach noclegowych, co wskazała ok. $1 / 3$ z nich (36\%) (rys. 1). Z mediów społecznościowych innych niż agregator opinii i/lub forum internetowe $(42 \%)$, takich jak: blog i/lub videoblog $(35 \%)$, serwis społecznościowy Facebook (30\%) i encyklopedia internetowa (30\%), uczestnicy ankiety korzystali rzadziej. Częściej szukali tam informacji turystycznej respondenci poniżej 35. roku życia. Agregator opinii i/lub forum internetowe wybrało ok. 50\% respondentów, serwis społecznościowy Facebook - blisko 40\%, a blog i/lub videoblog $-30 \%$. Takich odpowiedzi udzieliła średnio co piąta lub co szósta osoba w wieku powyżej 35 lat.

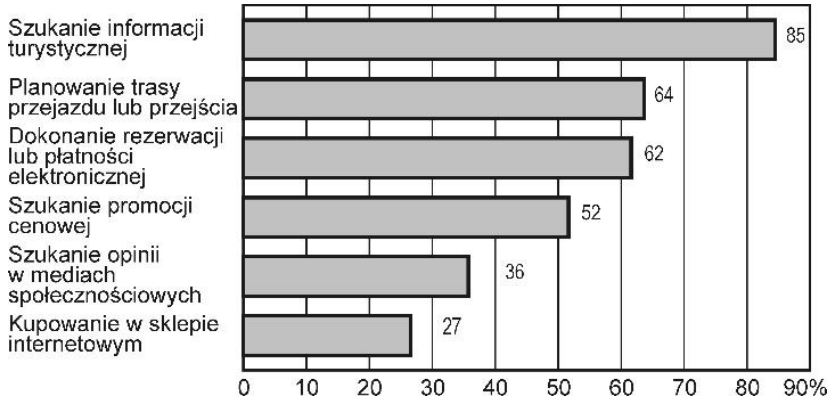

Rysunek 1. Cele korzystania z Internetu przed wyjazdem turystycznym (ujęcie \%).

Odpowiedzi nie sumują się do $100 \%$

(pytanie wielokrotnego wyboru)

Źródło: badania własne

Zamieszczanie informacji (przede wszystkim zdjęć) o swoim wyjeździe turystycznym w mediach społecznościowych zadeklarowało natomiast $44 \%$ respondentów, przy czym najbardziej aktywni byli oni podczas wyjazdu turystycznego. Wcześniej dodawali głównie oznaczenia miejsca pobytu (3\%) oraz krótkie (10\%) i dłuższe wpisy (2\%). Respondenci poniżej 35 . roku życia byli bardziej aktywni, przede wszystkim ci w wieku 15-18 lat. Aktywność ta łączyła się z częstością korzystania z Internetu przed wyjazdem turystycznym (test $\chi^{2}$ Pearsona $=$ 98,33, $p=0,000$ ).

Ponieważ ponad $1 / 3$ ankietowanych $(36 \%)$ szukała opinii $\mathrm{w}$ mediach społecznościowych, $\mathrm{w}$ zogniskowanych wywiadach grupowych zapytano ich o zainteresowanie działaniami twórców internetowych (np. blogerów i vlogerów) w kontekście wyjazdu turystycznego. Było ono widoczne wśród „młodszych" i „,starszych” respondentów, jednak podane przez nich powody różniły się (rys. 2). Wśród "starszych” dominowała opinia o wpływie tych treści na podejmowanie decyzji związanych z wyjazdem turystycznym, ze względu na merytoryczność informacji, sposób narracji, estetykę i profesjonalizm przygotowania, np. przy wykorzystaniu kamery sportowej GoPro, przeznaczonej do rejestrowania m.in. sportów ekstremalnych, lub drona. Byli oni świadomi, że udostępnione treści mogą być konsekwencją działań marketingowych, co większość z nich traktowała jako umniejszające wiarygodność. Natomiast „młodsi” byli zainteresowani życiem osobistym ulubionych twórców

Tabela 1. Częstość korzystania z Internetu przed wyjazdem turystycznym a wiek respondentów (ujęcie \%)

\begin{tabular}{|l|c|c|c|c|c|c|c|}
\hline \multirow{2}{*}{$\begin{array}{c}\text { Częstość korzystania } \\
\text { z Internetu }\end{array}$} & \multicolumn{6}{|c|}{ Odsetek odpowiedzi według wieku w latach (\%) } & Test Kruskala- \\
\cline { 2 - 8 } & $15-18$ & $19-25$ & $26-35$ & $36-45$ & $46-55$ & $>55$ & -Wallisa* \\
\hline Zawsze & 41 & 35 & 31 & 27 & 28 & 18 & $H=53,13, p=$ \\
\hline Często & 28 & 44 & 40 & 28 & 16 & 18 & 0,000 \\
\hline Czasami & 21 & 16 & 23 & 33 & 24 & 8 & \\
\hline Rzadko & 7 & 2 & 5 & 11 & 22 & 10 & \\
\hline Nigdy & 3 & 3 & 1 & 1 & 10 & 46 \\
\hline Razem & 100 & 100 & 100 & 100 & 100 & 100 & \\
\hline
\end{tabular}

*Różnice statystycznie istotne dla $p<0,05$.

Źródło: badania własne. 


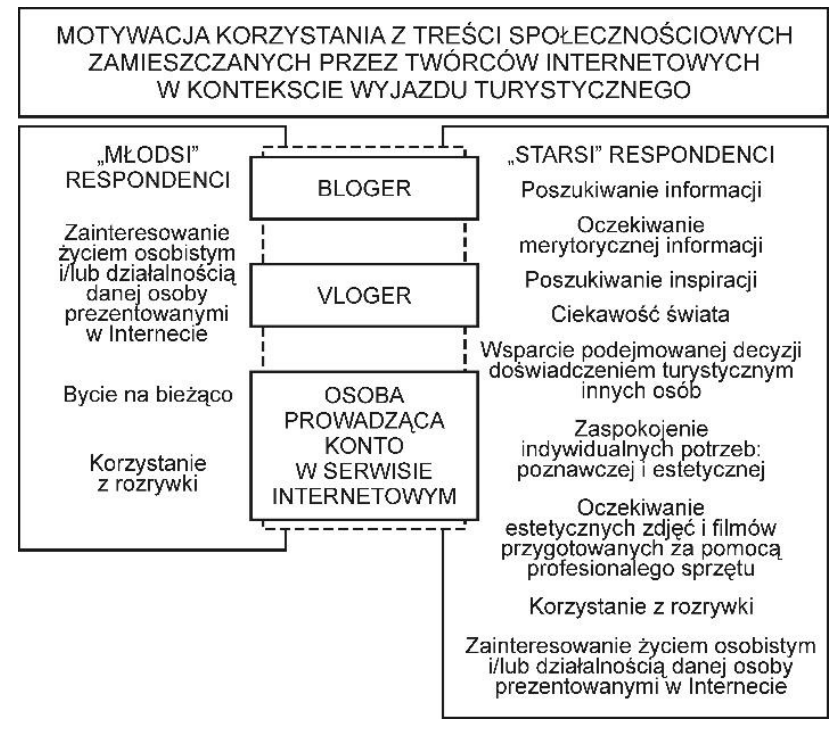

Rysunek 2. Motywacje korzystania z treści autorstwa twórców internetowych w kontekście wyjazdu turystycznego Źródło: badania własne

internetowych, którego częścią mogły być podróże, ale przede wszystkim materiałami związanymi z modą, urodą i grami komputerowymi.

W pytaniu o cele korzystania z Internetu drugą najczęściej pojawiającą się odpowiedzią było planowanie trasy przejazdu lub przejścia, co wskazało $64 \%$ respondentów (rys. 1). Odpowiedź ta była drugą - po szukaniu informacji turystycznej - najliczniejszą w każdej grupie wiekowej. Blisko $90 \%$ badanych w wieku do 35 lat i ok. $75 \%$ respondentów po 35. roku życia szukało informacji turystycznej, a $60 \%$ zaplanowało trasę. W grupie ankietowanych po 55. roku życia takiej odpowiedzi udzieliło ok. 33\% z nich.

Respondenci licznie wskazali również cele związane z płatnościami przez Internet (rys. 1). Ponad 60\% $\mathrm{z}$ nich zrobiło rezerwację i/lub dokonało płatności elektronicznej (62\%), np. za usługę noclegową lub bilet przejazdowy, a ponad połowa szukała promocji cenowej (52\%), m.in. w wyszukiwarce biletów lotniczych. Mniej liczne odpowiedzi dotyczyły kupowania w sklepie internetowym (27\%), np. sprzętu turystycznego. Bardziej aktywnymi użytkownikami były tu ponownie osoby z grupy wiekowej poniżej 35. roku życia. Z możliwości rezerwacji i/lub płatności elektronicznej skorzystało ok. $70 \% \mathrm{z}$ nich, a blisko $60 \% \mathrm{z}$ promocji cenowej i prawie $30 \%$ ze sklepu internetowego (starsi odpowiednio: ok. 50\%, 30\% i 20\%). Z kolei respondenci z miast o liczbie ludności powyżej 500 tys. częściej poszukiwali w Internecie promocji cenowej (63\%), a ci z mniejszych miast częściej kupowali w sklepie internetowym (34\%).

Większość respondentów co najmniej raz kupiła usługę turystyczną w Internecie (76\%), w tym 33\% przez zakupy grupowe. Zauważono, że grupa ta częściej poszukiwała informacji turystycznej w Internecie przed wyjazdem turystycznym (88\%). Ponad 80\% ankietowanych oceniło płatność elektroniczną jako bezpieczną (85\%), jednak ok. 1/4 osób, które zrobiły zakup, odpowiedziała przecząco (23\%). Zazwyczaj zakupu przez Internet dokonywali respondenci w wieku 26-35 lat (89\%), również przez zakupy grupowe (46\%), przy czym statystycznie częściej były to kobiety (71\%; test $\chi^{2}$ Pearsona, $p=0,018)$. Ta grupa wiekowa zadeklarowała największe zaufanie do płatności elektronicznych (94\%). Mieszkańcy miast częściej kupowali przez Internet (ok. 80\%) niż osoby z obszarów wiejskich (ok. 50\%), a dodatkowo respondenci z mniejszych miast korzystali blisko dwukrotnie częściej z zakupów grupowych niż pozostali (43\%).

\subsection{OCENA UŻYTECZNOŚCI NARZĘDZI CYFROWYCH}

Respondenci poproszeni o dokonanie wyboru między narzędziem tradycyjnym a cyfrowym, z którego chętniej skorzystaliby, chcąc dotrzeć do informacji i/lub usługi turystycznej, częściej wymieniali narzędzie cyfrowe (tab. 2). Dwoma wyjątkami były: opinia bliskiej osoby (71\%) i broszura drukowana (55\%).

Ponad 50\% badanych z grupy wiekowej między 15. a 35. rokiem życia wolało korzystać z narzędzi cyfrowych (oprócz opinii bliskiej osoby). Natomiast osoby nieco starsze, powyżej 35. roku życia, częściej używały narzędzi tradycyjnych, podobnie jak respondenci z wykształceniem zawodowym. Ankietowani z obszarów wiejskich woleli zakup w biurze podróży (64\%), natomiast w Internecie (ponad 50\%) kupowali mieszkańcy miast. Jednak to respondenci z miast liczących powyżej 500 tys. mieszkańców częściej wskazali materiały drukowane - mapę (52\%) i broszurę (64\%), a ankietowani z mniejszych miast - internetową mapę (68\%) i aplikację mobilną (53\%).

W opinii większości uczestników zogniskowanych wywiadów grupowych użytkownikami technologii informacyjno-komunikacyjnych byli przede wszystkim ludzie w wieku do 30 lub 40 lat. Jednak wzrost popularności i powszechności niektórych narzędzi cyfrowych, takich jak smartfon, i zmiana w ofercie handlowej sieci komórkowych oddziałują na decyzje nabywcze konsumentów, również ze starszych pokolen, poniekąd wymuszając konieczność nauki korzystania z tego typu technologii.

W skali pięciopunktowej respondenci najwyżej ocenili użyteczność tych narzędzi cyfrowych, które ułatwiały przemieszczanie się, czyli nawigacji GPS $(4,43)$, internetowej mapy $(4,25)$ i internetowego rozkładu jazdy transportu zbiorowego $(4,21)$. Relatywnie wysoko oceniono rezerwację i/lub płatność elektroniczną $(4,21)$. Bardziej cenionymi źródłami informacji turystycznej były strona internetowa odwiedzanego miejsca $(4,12)$ i obiektu noclegowego (4,01), niż aplikacja mobilna $(3,72)$ i media społecznościowe: blog i/lub videoblog $(3,71)$, agregator o pinii i/lub forum internetowe $(3,51)$ i serwis społecznościowy Facebook $(3,29)$. 
Tabela 2. Wybór między narzędziami dostępu do informacji i/lub usługi turystycznej (ujęcie \%)

\begin{tabular}{|c|c|c|c|}
\hline \multicolumn{4}{|c|}{ Narzędzie dostępu do informacji i/lub usługi turystycznej } \\
\hline Tradycyjne & Odsetek odpowiedzi & Cyfrowe & Odsetek odpowiedzi \\
\hline Przewodnik drukowany & 41 & Strona internetowa & 59 \\
\hline Mapa drukowana & 41 & Mapa internetowa & 59 \\
\hline Broszura drukowana & 55 & Aplikacja mobilna & 45 \\
\hline Punkt informacji turystycznej & 31 & Strona internetowa & 69 \\
\hline Zakup usługi w biurze podróży & 45 & Zakup usługi w Internecie & 55 \\
\hline Opinia bliskiej osoby & 71 & Opinia w Internecie & 29 \\
\hline Wydawnictwo albumowe & 40 & Wirtualny spacer & 60 \\
\hline
\end{tabular}

Źródło: badania własne.

W poszczególnych grupach wiekowych rozkłady odpowiedzi respondentów były zbliżone do ocen średnich, z wyjątkiem osób po 55. roku życia (najniższe oceny). Umiarkowane zależności korelacyjne były widoczne $\mathrm{w}$ dwóch przypadkach. Korzystający z Internetu przed wyjazdem turystycznym ocenili wyżej użyteczność wymienionych stron internetowych (rho-Spearmana $=0,31$ i 0,33 ). Natomiast aktywni w mediach społecznościowych w związku z wyjazdem turystycznym ocenili wyżej użyteczność mediów społecznościowych (rho-Spearmana $=0,31$. .

Młodsi uczestnicy zognisokowanych wywiadów grupowych nie łączyli ściśle korzystania z narzędzi cyfrowych $\mathrm{z}$ ułatwieniami w organizacji wyjazdu turystycznego, traktując je jako narzędzie mu "towarzyszące", np. przez dodawanie zdjęć w serwisach społecznościowych z wycieczki szkolnej lub korzystanie z gier na smartfonie podczas przejazdu autokarem. Podkreślili natomiast wpływ mody i środowiska rówieśniczego na potrzebę korzystania np. z określonych modeli smartfonów lub aplikacji mobilnych. Również ,starsi" respondenci zwrócili uwagę na ten aspekt, jednak duże znaczenie miały dla nich wspomniane ułatwienia. Zaznaczali przede wszystkim użyteczność zasobów informacyjnych w Internecie, a nie rozrywkowy charakter treści, jak robili to „młodsi” uczestnicy, co nie znaczy, że nie miało to dla nich znaczenia (rys. 2). Jako przykłady wymienili najczęściej zasoby informacyjne $\mathrm{w}$ Internecie, nawigację GPS $i$ internetowe mapy oraz rezerwację i/lub płatności elektroniczne. "Starsi” respondenci mieli zdecydowanie większą wiedzę i umiejętności dotyczące funkcji narzędzi cyfrowych, m.in. dlatego, że jako osoby pełnoletnie korzystali ze sklepów internetowych i płatności elektronicznych.

\section{PODSUMOWANIE}

Rozwój technologii informacyjno-komunikacyjnych znacząco przyczynił się do rozszerzenia dostępu do informacji i usług turystycznych przez zastosowanie kanałów elektronicznych, przede wszystkim Internetu i urzą- dzeń przenośnych, głównie smartfona. W celu poznania aktywności uczestników ruchu turystycznego w Internecie przeprowadzono w latach 2014-2016 badania ankietowe w ośrodkach turystycznych województwa małopolskiego na próbie 1053 osób.

Badania te pozwoliły na stwierdzenie, że respondenci aktywnie korzystali z technologii informacyjno-komunikacyjnych przed wyjazdem turystycznym, aby uzyskać dostęp do informacji i usług. Największe zainteresowanie i najwyższe oceny użyteczności były widoczne na przykładzie narzędzi cyfrowych dających dostęp do szeroko rozumianej informacji ułatwiającej organizację wyjazdu turystycznego, przede wszystkim w zakresie planowania, przemieszczania się i korzystania z atrakcji turystycznych. Na podstawie uzyskanych wyników, można zatem stwierdzić, że technologie informacyjno-komunikacyjne mają wpływ na kształtowanie doświadczenia turystycznego. Jest to ciekawy obszar do dalszych badań szczegółowych.

Odpowiedzi ankietowanych osób pozwoliły na wyodrębnienie grupy turystów najaktywniej korzystających z technologii informacyjno-komunikacyjnych. Są to 20-i 30-latkowie - co odpowiada cechom pokolenia Y - wykorzystujący rozwiązania cyfrowe nie tylko jako źródła informacji i narzędzia dostępu do usług turystycznych, ale również $\mathrm{w}$ ramach aktywności $\mathrm{w}$ mediach społecznościowych.

Mimo dość dużego społecznego zainteresowania korzystaniem z technologii informacyjno-komunikacyjnych, na rynku turystycznym w Polsce nadal są obecni liczni turyści preferujący narzędzia tradycyjne. Dlatego ciągle jest konieczność dwukierunkowego kształtowania komunikacji marketingowej - a szerzej polityki informacyjnej - podmiotów gospodarki turystycznej.

\section{PRZYPIS}

${ }^{1}$ Badania, których wyniki omówiono w artykule, były finansowane z Projektu „Doctus - Małopolski fundusz stypendialny dla doktorantów" Urzędu Marszałkowskiego Województwa Małopolskiego w latach 2012-2015 oraz ze środków DS Wydziału Biologii 
i Nauk o Ziemi Uniwersytetu Jagiellońskiego w Krakowie w latach 2013-2016 w ramach projektów: K/DSC/001787 i K/DSC/002377. Wyniki te są częścią rozprawy doktorskiej pt. Wykorzystanie technologii informacyjno-komunikacyjnych (ICT) $w$ działaniach promocyjnych i informacji turystycznej w gminach województwa matopolskiego.

\section{BIBLIOGRAFIA}

Amaro, S., Duarte, P. (2015). An integrative model of consumers intentions to purchase travel online. Tourism Management, 46, 64-79.

Berbeka, J. (2017). Analiza wykorzystania technologii informacyjnych i komunikacyjnych przez odwiedzających Kraków. W: J. Berbeka, K. Borodako (red.), Technologie informacyjne i komunikacyjne na rynku turystycznym (s. 153-171). Warszawa: Wydawnictwo C.H. Beck.

Buhalis, D. (2003). eTourism: Information technology for strategic tourism management. Essex: Pearson Education Limited.

Buhalis, D., Law, R. (2008). Progress in information technology and tourism management: 20 years on and 10 years after the Internet - The state of eTourism research. Tourism Management, 29 (4), 609-623.

Buhalis, D., O'Connor, P. (2005). Information communication technology revolutionizing tourism. Tourism Recreation Research, 30 (3), 7-16.

Buhalis, D., Leung, D., Law, R. (2011). eTourism: Critical information and communication technologies for tourism destinations. W: Y. Wang, A. Pizam (red.), Destination marketing and management: Theories and applications (s. 205-224). Oxford: CAB International.

Gaworecki, W.W. (2007). Turystyka. Warszawa: Polskie Wydawnictwo Ekonomiczne.

Giddens, A. (2008). Socjologia. Warszawa: Wydawnictwo Naukowe PWN.

Gretzel, U., Sigala, M., Xiang, Z., Koo, Ch. (2015). Smart tourism: Foundations and developments. Electronic Markets, 25 (3), 179-188.

Hall, M.C. (2006). Space-time accessibility and the TALC: The role of geographies of spatial interaction and mobility in contributing to an improved understanding of tourism. W: R. Butler (red.), The tourism area life cycle: Conceptual and theoretical issues. Część 2 (s. 83-100). Clevedon-Buffalo-Toronto: Channel View Publications.

Horner, S., Swarbrooke, J. (2016). Consumer behaviour in tourism. Oxon-New York: Routledge.

Jakubowska, M. (2018). Diagnoza form turystyki popularyzowanych przez blogerów podróżniczych w Polsce. Studia Oeconomica Posnaniensia, 6 (10), 76-92.

Jaremen, D.E., Michalska-Dudek, I., Rapacz, A. (2016). Wirtualizacja zachowań konsumentów na rynku turystycznym jako źródło wiedzy w podejmowaniu decyzji marketingowych. Studia i Prace Wydziału Nauk Ekonomicznych i Zarzadzania Uniwersytetu Szczecińskiego, 43 (2), 85-93.

Jednoralska, A. (2016). Profil polskiego blogera podróżniczego - blogerzy podróżniczy jako inicjatorzy alternatywnego podróżowania wśród Polaków. Turystyka i Rekreacja, 13 (2), 29-33.

Kachniewska, M. (2011). Wpływ nowych technologii na rynek usług pośredników turystycznych. Zeszyty Naukowe Kolegium Gospodarki Światowej, 32, 239-258.

Kachniewska, M. (2014). Big data analysis jako źródło przewagi konkurencyjnej przedsiębiorstw i regionów turystycznych. Folia Turistica, 32, 35-54.
Kachniewska, M. (2017). Zmiany na rynku turystycznym. Nowe modele biznesowe i polityka turystyczna. Studia Oeconomica Posnaniensia, 5 (4), 183-207.

Kim, D.-Y., Park, J., Morrison, A.M. (2008). A model of traveller acceptance of mobile technology. International Journal of Tourism Research, 10, 393-407.

Kotler, P., Bowen, J.T., Makens, J.C. (2006). Marketing for hospitality and tourism. Upper Saddle River: Prentice-Hall.

Kowalczyk, A. (2000). Geografia turyzmu. Warszawa: Wydawnictwo Naukowe PWN.

Kubiak, K. (2015). Ocena wybranych aplikacji mobilnych w opinii użytkowników. Zeszyty Naukowe Uniwersytetu Szczecińskiego, 875. Problemy Zarzadzania, Finansów i Marketingu, 41 (2), 83-93.

Law, R., Buhalis, D., Cobanoglu, C. (2014). Progress on information and communication technologies in hospitality and tourism. International Journal of Contemporary Hospitality Management, 26 (5), 727-750.

Lisowska, A., Wieszaczewska, A. (2017). Santiago de Compostela jako ważna destynacja turystyki pielgrzymkowej - obraz pielgrzymowania w narracjach blogów podróżniczych. Turystyka Kulturowa, 3, 74-95.

Majewska, J., Napierała, T., Adamiak, A. (2016). Wykorzystanie nowych technologii i informacji do opisu przestrzeni turystycznej. Folia Turistica, 41, 309-338.

Marciszewska, B. (2010). Produkt turystyczny a ekonomia doświadczeń. Warszawa: Wydawnictwo C.H. Beck.

Meyer, B. (2015). Współczesne trendy w turystyce i rekreacji. W: B. Meyer (red.), Obstuga uczestników turystyki i rekreacji (s. 29-33). Warszawa: Wydawnictwo Difin.

Mika, M. (2014). Założenia i determinanty podtrzymywalności lokalnego rozwoju turystyki. Kraków: Instytut Geografii i Gospodarki Przestrzennej Uniwersytetu Jagiellońskiego w Krakowie.

Morozova, I. (2016). Blog podróżniczy jako przestrzeń dla kreowania i komunikowania wzorców podróży. Folia Turistica, 40, 119-133.

Munar, A.M., Jacobsen, J.K.S. (2014). Motivations for sharing tourism experiences through social media. Tourism Management, 43, 46-54.

Neuhofer, B., Buhalis, D., Ladkin, A. (2012). Conceptualising technology enhanced destination experiences. Journal of Destination Marketing \& Management, 1 (1-2), 36-46.

Neuhofer, B., Buhalis, D., Ladkin, A. (2014). A typology of technology-enhanced tourism experiences. International Journal of Tourism Research, 16 (4), 340-350.

Niemczyk, A. (2017a). Rola technologii mobilnych na rynku turystycznym. W: J. Berbeka, K. Borodako (red.), Technologie informacyjne i komunikacyjne na rynku turystycznym (s. 93-116). Warszawa: Wydawnictwo C.H. Beck.

Niemczyk, A. (2017b). Aplikacje mobilne jako determinanta zachowań turystycznych (na przykładzie Krakowa). Prace Naukowe Uniwersytetu Ekonomicznego we Wrocławiu, 473, 370-381.

Niininen, O., Buhalis, D., March, R. (2007). Customer empowerment in tourism through consumer centric marketing (CCM). Qualitative Market Research: An International Journal, 10 (3), 265-281.

Panasiuk, A. (2015). Nowe technologie informacyjne w kształtowaniu innowacji na rynku turystycznym. Rozprawy Naukowe Akademii Wychowania Fizycznego we Wroctawiu, 49, 99-106.

Pawłowska, A. (2015). Turysta 2.0 - wyniki badania ankietowego nt. wykorzystania nowych technologii przez turystów w województwie małopolskim. Episteme. Czasopismo Naukowo-Kulturalne, 2 (23), 271-282.

Pawłowska, A. (2016a). Tourists and social media: Already inseparable marriage or still a long-distance relationship? Analysis of focus group study results conducted among tourists using 
social media. World Scientific News. International Scientific Journal, 57, 106-115.

Pawłowska, A. (2016b). Aplikacje mobilne jako nowe narzędzie w informacji turystycznej. Wyniki badań przeprowadzonych w województwie małopolskim. W: I. Miciuła, I. NowakowskaGrunt (red.), Wybrane aspekty w zarządzaniu organizacją w XXI w. Innowacje - Gospodarka - Społeczeństwo (s. 371-383). Katowice: Wydawnictwo Naukowe Sophia.

Pietro, L. di, Virgilio, F. di, Pantano, E. (2012). Social network for the choice of tourist destination: Attitude and behavioural intention. Journal of Hospitality and Tourism Technology, 3 (1), 60-76.

Poczta, J., Mariianchuk, M. (2013). Samoświadomość turysty kulturowego a wizualność turystycznego świata, powszechność fotografii i ich wpływ na jakość turystycznego przeżywania. Turystyka Kulturowa, 11, 32-47.

Rasińska, R., Siwiński, W. (2015). Aplikacje mobilne jako innowacyjne źródła informacji turystycznej dla studentów. Rozprawy Naukowe Akademii Wychowania Fizycznego we Wroctawiu, 50, 74-80.

Richards, G. (2002). Tourism attraction system. Exploring cultural behavior. Annals of Tourism Research, 4 (29), 1048-1064.

Rudnicki, M. (2017). Rozwiązania informacyjno-komunikacyjne $\mathrm{w}$ przedsiębiorstwach turystycznych. W: J. Berbeka, K. Borodako (red.), Technologie informacyjne i komunikacyjne na rynku turystycznym (s. 31-64). Warszawa: Wydawnictwo C.H. Beck.

Seweryn, R. (2015). Profil turysty pozyskującego informacje o destynacji z mediów społecznościowych (na przykładzie od- wiedzających Kraków). Prace Naukowe Uniwersytetu Ekonomicznego we Wrocławiu, 379, 439-447.

Smul, P. (2013). Wykorzystanie Internetu w sprzedaży i promocji usług turystycznych. Zeszyty Naukowe Wyższej Szkoły Humanitas. Zarzadzanie, 14 (1), 88-104.

Xiang, Z., Gretzel, U. (2010). Role of social media in online travel information search. Tourism Management, 31, 179-188.

Xiang, Z., Magnini, V.P., Fesenmaier, D.R. (2015). Information technology and consumer behavior in travel and tourism: Insights from travel planning using the internet. Journal of Retailing and Consumer Services, 22, 244-249.

Zajadacz, A. (2014). Pokolenia X, Y, Z a fenomen turystyki. W: J. Śledzińska, B. Włodarczyk (red.), Międzypokoleniowe aspekty turystyki (s. 55-68). Warszawa: Wydawnictwo PTTK Kraj.

Zajadacz, A. (2017). Dyssatysfakcja w przestrzeni turystycznej. Negatywne opinie użytkowników Tripadvisor na temat głównych atrakcji turystycznych wybranych miast w Polsce. Prace i Studia Geograficzne, 62 (3), 63-88.

Zawadzki, P. (2018). Aplikacje mobilne jako element systemu informacji turystycznej. Zeszyty Naukowe Uniwersytetu Ekonomicznego w Krakowie, 4, 85-101.

Zehrer, A., Pechlaner, H., Holzl, B. (2005). The development of a Destination Management System (DMS) in South Tyrol. Anatolia, 16 (2), 147-161.

Zeng, B., Gerritsen, R. (2014). What do we know about social media in tourism? A review. Tourism Management Perspectives, 10, 27-36. 
